\title{
Bacteriological Quality of Fresh Vegetables and Peeled Sugar-Cane Obtained from Selected Markets in Zaria, Nigeria
}

\author{
Igba P.*1 Tytler B. A. ${ }^{1} \quad$ Hamza, J. A. $^{2} \quad$ Adeshina G. O. ${ }^{1}$ \\ 1. Department of Pharmaceutical Microbiology, Ahmadu Bello University Zaria Nigeria \\ 2. Department of Pharmaceutical Microbiology and Biotechnology, Gombe State University, Nigeria
}

\begin{abstract}
Fresh vegetables and peeled sugar-cane serves as an essential component of a healthy diet, but despite their benefit they are prompt to bacterial contamination. The bacteriological quality of four types of fresh vegetables and peeled sugar-cane obtained from selected markets in Zaria, Nigeria was determined using standard microbiological method. The fresh vegetables, peeled sugar-cane, water and hand-swab samples were collected from four different locations namely; Samaru, Sabon-gari, Tudun-wada and Zaria-city. The total bacteria plate counts ranged from $3.3 \times 10^{6} \mathrm{cfu} / \mathrm{g}$ to $1.6 \times 10^{7} \mathrm{cfu} / \mathrm{g}$ with Tudu-wada having the highest bacteria load in lettuce. The coliform count of fresh vegetables and peeled sugar-cane varies from $1.3 \times 10^{4}$ to $8.6 \times 10^{5} \mathrm{cfu} / \mathrm{g}$ in the entire markets with Tudu-wada having the highest value in cucumber, the counts were obviously above specified Standard of $10^{5} \mathbf{~ c f u / g}$ and $10^{3} \mathbf{c f u} / \mathbf{g}$ (ICMSF, 1978). Pathogenic bacteria isolated include; Citrobacter fruendii, Escherichia coli, Enterobacter spp., Klebsiella. spp., Shigella spp., Serratia spp., Cronobacter sakazaki, Staphylococcus aureus, Pseudomonas spp., and others Staphylococci spp.. This study showed that, fresh vegetables and peeled sugar-cane are contaminated with pathogenic bacteria making them unsafe for human consumption; hence fresh produce should be pre- treated thoroughly, so as to reduce the risk of food- borne outbreaks.
\end{abstract}

Keywords: Pathogenic bacteria - Bacteriological quality, Microbiological method, Coliform counts and foodborne outbreaks.

DOI: $10.7176 / \mathrm{JNSR} / 12-8-02$

Publication date: April $30^{\text {th }} 2021$

\section{INTRODUCTION}

Foodborne illnesses are major public health problem which have led to an increase in morbidity and mortality worldwide (Scallan et al., 2011). Globally, an estimate of 2 million people died from diarrheal diseases in 2005 and approximately, $70 \%$ of these were foodborne-poisonous related (WHO, 2011). The illnesses in about 2 million of these people were related to consumption of contaminated fresh vegetables.

Fresh vegetables and peeled sugar cane serves as an essential ingredient of a healthy diet, the consumption rate of these fresh produce and peeled sugar-cane has been increased worldwide. Fresh vegetables and peeled sugar-cane are extraordinary dietary source of nutrients, micronutrients, carbohydrates, anti-oxidants, minerals, vitamins and fibres (Prigulkar, et al., 2000; Reena, et al., 2012; Sararaj et al., 2014) and often consumed uncooked. But despite their health benefits; these fresh vegetables and peeled sugar-cane consumption is a risk for consumers (Soltan et al., 2015).

Fresh vegetables and peeled sugar-cane are so vital for human health and well-being, but despite their benefits to healthy living, fresh vegetables and peeled sugar-cane have been reported for their contamination with pathogenic bacteria such as Clostridium perfringes, Escherichia coli, Staphylococcus aureus, Streptococcus spp., Salmonella typhi, Shigella spp., Lysteria monocytogenes, Yesinia enterocolitia, Campylobacter jejuni, Vibrio spp., Pseudomonas spp., Aeromonas spp., and Campylobacter coli has been reported in different regions of the world (Bukar, et al., 2010; Reena, et al., 2012; Eni et al., 2010; Nwankwo, et al., 2013 and Denis, et al., 2016).

During harvesting and transportation, fresh vegetables and peeled sugar cane may be bruised thereby, providing substrates for microorganisms present on the surface of the vegetable to grow as a resulting of plant nutrients released (Nwankwo et al., 2015). Production and processing of fresh vegetables and peeled sugar-cane, probably account for the level of contamination observed. Use of questionable quality inputs including used of poor quality irrigation water and poor labourer hygiene have all been identified as possible sources of contamination (Golly et al., 2016)

Fresh vegetables and peeled sugar cane consumption either raw or uncooked can be the important risk factor for the transmission of pathogens (Sararaj et al., 2012). A number of reported foodborne outbreak and chronic infections have been cause by pathogenic bacteria from fresh produce (Eni et al., 2010 and Oliveira et al., 2011). There is therefore a need to evaluate the current risk that consumers of fresh vegetables are exposed to in Zaria metropolis. 


\section{MATERIALS AND METHODS}

A total of (160) sample of fresh vegetables (carrot, cabbage, cucumber, lettuce) and peeled Sugar cane (40), hand swabs of vegetables vendors (11), and the water used in sprinkling these fresh produce (29), were collected within April to June 2019 from open markets in Zaria City, Samaru, Tudun-wada and Sabon-Gari locations of Zaria, Kaduna State. Different markets samples were collected on separate days from distinct vendors. Within 24 hours of collection, samples were transported promptly to the laboratory for analysis.

\section{Water and Hand-Swab sample collection}

The water samples $(n=26)$ used for sprinkling the fresh vegetables and peeled sugar-cane were collected from the storage containers into sterile containers. During transporting the samples, sterile plastic containers were used. $10 \mathrm{ml}$ of each water sample were diluted in $90 \mathrm{ml}$ sterile normal saline. Standard Serial dilution procedure was further carried out using pour plate method. Eleven (11) hand-swab samples were collected from fresh produce and peeled sugar-cane vendors with sterile swab sticks moistened in $0.1 \%$ sterile peptone water, by swabbing the palms of the vendors; aseptic techniques was used to avoid contamination.

\section{Evaluation of this samples}

To suspend the phyllosphere-associated microorganisms from the surface of cabbage, cucumber, carrot, sugar cane and lettuce, $25 \mathrm{~g}$ of fresh vegetable and peeled sugar-cane sample was added to each conical flask containing $225 \mathrm{ml}$ sterile peptone water. Sample was then agitated separately in the sterile conical flask for 25 min to suspend surface microbes (Seow et al., 2012). Hand swabs of vegetables vendors, and the water samples were analyzed.

\section{Culture}

Standard microbiological protocol was used to determined total bacteria and total coliform count. Serial dilution was made for each samples; $1 \mathrm{ml}$ of each step was inoculated into duplicates of Nutrient agar (NA) plates and MacConkey agar plates (Himedia) (Sospedra et al., 2013). The plates were incubated at $37{ }^{\circ} \mathrm{C}$ for 24 hours (Sujeet et al., 2017). The colonies formed on the plates were counted using colonies counter and expressed as $\log _{10}$ colony-forming unit/g $(\log \mathrm{cfu} / \mathrm{g})$.

\section{Aerobic colony count of swab samples}

Each $10 \mathrm{ml}$ of sterile distilled water in test-tubes containing swab-stick were left standing for 30minutes. New prepared $90 \mathrm{ml}$ of sterile distilled water was thoroughly mixed with $10 \mathrm{ml}$ of sterile distilled water containing swab stick. $1 \mathrm{ml}$ of the mixture was then transferred to a test-tube containing $9 \mathrm{ml}$ of sterile distilled water, further serial dilutions was made. Exactly $0.5 \mathrm{ml}$ of serial dilutions $10^{-2} 10^{-3}$ and $10^{-4}$ were cultured on Nutrient Agar, Mannitol salt agar and MacConkey agar petri dishes, using pour plate method. Which were further incubated at $37^{\circ} \mathrm{C}$ for 24 hours. The number of colonies seen counted using colonies seen were counted using a colony counter and recorded as colony forming unit per gram $(\mathrm{cfu} / \mathrm{ml})$.

\section{B) Biochemical tests:}

This biochemical tests were used, which include catalase, coagulase, motility, indole, oxidase, citrate, malonate, methyl red, Voges Proskauer (MRVP), Triple iron sugar (TSI) for Identification and characterization of isolates.

\section{Microgen Identification kits}

The bacterial isolates were further confirmed using standard commercially available Identification kits (Microgen ID kit).

\section{RESULT}

Both fresh vegetables and peeled sugar-cane contained a variety of bacterial groups. The mean total bacterial counts and the coliform count for the fresh vegetables and peeled sugar cane are shown in (Table 1. and 2). Lettuce had the highest mean count of $1.6 \times 10^{7} \mathrm{cfu} / \mathrm{g}$. The coliform count was highest in cucumber $(8.6 \mathrm{x}$ $\left.10^{5} \mathrm{cfu} / \mathrm{g}\right)$.

The total bacterial colony count from the hand of all the eleven $(n=11)$ fresh produce vendors from the various locations studies ranged between $1.3 \times 10^{4}-7.6 \times 10^{4} \mathrm{cfu} / \mathrm{g}$ as show in table 3 . 
Table 1: Mean of Total Bacteria Count $(\mathrm{cfu} / \mathrm{g})$ of fresh vegetables and peeled sugar cane by their location of purchase within Zaria markets.

\begin{tabular}{lllll}
\hline Samples & & Zaria Markets & \\
\hline & Samaru & Sabo-gari & Tudu-wada & Zaria-city \\
Cabbage & $7.4 \times 10^{6}$ & $6.9 \times 10^{6}$ & $5.8 \times 10^{6}$ & $1.2 \times 10^{7}$ \\
Carrot & $1.1 \times 10^{7}$ & $8.4 \times 10^{6}$ & $8.4 \times 10^{6}$ & $1.2 \times 10^{7}$ \\
Cucumber & $4.8 \times 10^{6}$ & $7.8 \times 10^{6}$ & $1.2 \times 10^{7}$ & $8.0 \times 10^{6}$ \\
Lettuce & $1.0 \times 10^{7}$ & $1.4 \times 10^{7}$ & $1.6 \times 10^{7}$ & $1.5 \times 10^{7}$ \\
Sugar-cane & $3.4 \times 10^{-6}$ & $3.3 \times 10^{-6}$ & $1.1 \times 10^{-7}$ & $7.0 \times 10^{-6}$ \\
\hline
\end{tabular}

Table 2: Mean of Total Coliform Count (cfu/g) of fresh vegetables and peeled sugar cane by their location of purchase within Zaria markets.

\begin{tabular}{lllll}
\hline Samples & & Zaria Markets & \\
\hline & Samaru & Sabo-gari & Tudu-wada & Zari-city \\
Cabbage & $1.1 \times 10^{5}$ & $8.3 \times 10^{5}$ & $3.9 \times 10^{4}$ & $1.7 \times 10^{5}$ \\
Carrot & $8.2 \times 10^{4}$ & $1.0 \times 10^{5}$ & $8.1 \times 10^{4}$ & $1.2 \times 10^{5}$ \\
Cucumber & $8.1 \times 10^{4}$ & $3.2 \times 10^{4}$ & $8.6 \times 10^{5}$ & $6.9 \times 10^{4}$ \\
Lettuce & $1.5 \times 10^{5}$ & $1.0 \times 10^{5}$ & $2.3 \times 10^{4}$ & $2.7 \times 10^{5}$ \\
Sugar-cane & $1.3 \times 10^{4}$ & $2.2 \times 10^{4}$ & $4.9 \times 10^{4}$ & $2.1 \times 10^{4}$ \\
\hline
\end{tabular}

Table 3: Mean of Total Bacteria count from vegetable vendors and peeled sugar-cane (hand swab) in Zaria markets

\begin{tabular}{lll}
\hline Location & AMC $(\log$ CFU/g) & TCC (Log CFU/g) \\
\hline Samaru & $7.1 \times 10^{4}$ & $1.3 \times 10^{4}$ \\
Sabo-gari & $7.6 \times 10^{4}$ & $2.8 \times 10^{4}$ \\
Tudu-wada & $3.2 \times 10^{4}$ & $2.3 \times 10^{4}$ \\
Zaria-city & $3.7 \times 10^{4}$ & $7.0 \times 10^{4}$ \\
\hline
\end{tabular}

Key: $\mathrm{AMC}=$ Aerobic mesophillic count, $\mathrm{TCC}=$ Total coliform count, $\mathrm{CFU} / \mathrm{g}=$ colony forming unity per grams.

Water samples obtained from the vegetable vendors were also contaminated with bacterial species with colony count ranging from $2.0 \times 10^{7}-1.1 \times 10^{8} \mathrm{cfu} / \mathrm{ml}$ (Table 4).

Table 4: Mean of Total Bacteria count from water sample for rinsing the vegetables and peeled sugar cane in Zaria markets

\begin{tabular}{lll}
\hline Location & AMC (log CFU/ml) & TCC (Log CFU/ml) \\
\hline Samaru & $8.5 \times 10^{7}$ & $3.7 \times 10^{7}$ \\
Sabo-gari & $1.1 \times 10^{8}$ & $3.0 \times 10^{7}$ \\
Tudu-wada & $7.0 \times 10^{7}$ & $3.0 \times 10^{7}$ \\
Zaria-city & $9.4 \times 10^{7}$ & $2.0 \times 10^{7}$ \\
\hline
\end{tabular}

Key: $\mathrm{AMC}=$ Aerobic mesophillic count, $\mathrm{TCC}=$ Total coliform count, $\mathrm{CFU} / \mathrm{ml}=$ colony forming unity per millitre.

Tables 5: Frequency of Bacteria Isolates from all samples

\begin{tabular}{|c|c|}
\hline Bacteria & Frequency \\
\hline S. aureus & $45(20.8 \%)$ \\
\hline Staphylococcus spp. & $54(25 \%)$ \\
\hline Enterobactericeae & $92(42.6 \%)$ \\
\hline Non-Enterobactericeae & $25(11.6 \%)$ \\
\hline Total & $216(100 \%)$ \\
\hline
\end{tabular}

The microorganisms isolated from fresh vegetables, peeled sugar-cane, water and hand swab samples include; Citrobacter fruendii, Escherichi. coli, Enterobacter spp., ( E. aerogene, E. gergovia and E. cloacae) Kleppsiella. Spp., (K. oxytoca, K. ozaenae, K. pneumonia); Acinetobacter spp. (A. baumanii, A. haemolyticus and A. Iwoffii), Shigella sonnei., Serratia spp., (S. liquefaciens, S. marcensens and S. Serratia rubidae); Cronobacter sakazaki, Staphylococcus aureus, Pseudomonas pp. and other Staphylococci spp..

\section{DISCUSSION}

Freshly consumed vegetables and peeled sugar-cane, have been the cause of food poisoning and thus a risk to the health of the consumers and the society as a whole (Gitahi el al., 2012). Generally, most fresh vegetables and peeled sugar-cane sampled in this study are contaminated with various bacterial types. Bacteria count exceeded 
International Commission on Microbiological Specification for Food (2006) guideline acceptable limit (100000tbc/25g). Due to unhygienic practices within the markets, this fresh produce and peeled sugar-cane are contaminated (Eni et al., 2010; Oji et al., 2016). The observation of high bacteria counts of this fresh vegetables and peeled sugar cane in this study are similar to those obtained in other studies in Nigeria (Abdullahi et al., 2010; Oji et al., 2016; Eni et al., 2010) but dissimilar to the findings of (Osamwonyi et al., 2013, Nwankwo et al., 2015 and Uzeh et al., 2009), who observed less bacteria load for bacteria compared to these study. This could be possibly due to the markets were these fresh vegetables were obtained.

Coliforms are usually indicators whose presence will normally indicate the probable presence of pathogenic organisms. Coliform count exceeded Food and agricultural organization (2008) guideline acceptable limit. The use of irrigation water on fresh vegetables and peeled sugar-cane in the respective markets has led high count in coliform, which indicates that E. coli can be transferred to vegetables even through irrigation water. A similar study on the bacterial quality of vegetables in Kano also showed a high count of coliform in fresh produces (Aliyu et al, 2005).

Among the isolated bacterial pathogens Enterobacter spp, S. aureus, Klebsiella sp, Acinetobacter spp, E. coli, Serratia spp, , Pseudomonas spp, Cronobacter spp, Citrobacter spp Shigella spp. were the predominant bacteria found to be associated with most of these fresh vegetable and peeled sugar-cane analyzed. The ability of $S$. aureus to cause a wide range of infections especially food- borne intoxication is a major public health problem (Tambekar and Mundhada, 2006, Aboh et al., 2011). Klebsiella spp. and E. coli are common within the environment. The prominent inhabitant of soil and water is Pseudomonas spp. The organism is responsible for diseases of vegetables like angular leaf spot of cucumber (Uzeh et al., 2009). The presence of these pathogens in fresh vegetable and peeled sugar-cane is a public health concern, as it has been implicated in several diseases (cardiovascular disease, chronic obstructive pulmonary disease and gastroenteritis). The condition of sales makes the fresh vegetables predisposed to contamination especially as practiced in Zaria where the source of water in the garden and in the market is questionable (Caron and Walker, 2004).

From the results obtained, this can expose the consumer to health risk. Therefore it is recommended that these fresh vegetables and peeled sugar-cane be thoroughly washed with clean water before consumption in other to avoid unhygienic practice.

\section{Conclusion}

The bacterial counts and the coliform obtained were high above specified standard. The presence of these pathogens in the fresh vegetable samples could serve as an indicator for the need to promote awareness about the possible health hazards that could be due to poor handling of these fresh produces. There is therefore, the need for agencies to ensure that microbiological standards are established and practiced by fresh vegetables and peel sugar vendors for the handling distribution of fresh vegetables and preparation like washing with salt and clean water since these vegetables are highly patronized. This could help in reducing the bacterial load eventually before consumption.

\section{REFERENCE}

Abdullahi, I.O., Abdulkareem, S. (2010). Bcaterial Quality of Some Ready-to-Eat Vegetables as Retailed and Consumed in Sabon-Gari, Zaria. Nigeria. Bayero Journal of pure and applied Science, 3(1): 173-175

Aboh M.I., Oladosu, P. Ibrahim, K, (2011). Bacterial contamination of salad vegetables in Abuja municipal area Council, Nigeria. Malaysian Journal of Microbiology, 7(2): 111-114

Aliyu, Y.U, Bassey, S.E and Kawo, A.H (2005). Bacteriological quality of vegetables sold in some shops around Kano metropolis, Nigeria. Biological and Environmental Sciences Journal for the Tropics, 2(1): 145 - 148

Bukar, A., Uba, A. and Oyeyi, T.I. (2010). Occurrence of some enteropathogenic bacteria in some minimally and fully processed ready-to-eat foods in kano metropolis, Nigeria. African Journal of Food Science, 4(2); 032-036

Caron, D and walker, D (2004). Green lafy vegetables. http//agudel.edu/xtension/horticulture/pdf/hg/hg-15pdf. Retrieved on $15 / 08 / 2008$

Denis, N, Zhang, H. Leroux, A. Trudel, R. Bietlot, H. (2016). Prevalence and trends of bacterial contamination in fresh fruits and vegetables sold at retail in Canada. Food Control, 67:225-234.

Eni, O.A., Oluwawemitan, I.A. and Solomon, O.U. (2010). "African Microbial Quality of Fruit and Vegetables Sold in Sango Ota, Nigeria. Journal of Food Science, 4(5):291- 296.

FDA. (2008). Guide to Minimize Microbial Food Safety Hazards of Fresh-Cut Fruits and Vegetables. 4,

Kim, J.K. and Harrison, M.A. (2008). Transfer of E, coli 0157:H7 to Romaine lettuce due to contact water from melting ice. Journal of Food protection 71 (2): 252- 256

Nwankwo, I.U, Eze, V.C. Onwuakor, C.E, Friday, J.U. (2015). Evaluation of the degree of contamination of salad Vegetable sold in Umuahia main Market. America Journal of Microbiology Reseach, 3. 41-44

Oliveira, M.A.D. Souza, V.M.D. Bergamini, A.M.M. and Martinis, E.C.P.D. (2011). 
Oji, Promise C. (2016). Bcateriological analysis of salad vegetable in Eke Awka Mraket Anambra State, Nigeria. International Journal of Scienctific and Research, Publications. Vol.6

Pesewu, G. A., Gyimah, I. K., Agyei, J. N. Y. K., Adjei, D. N., Olu-Taiwo, M. A., Asmah, R. H., and AyehKumi, P.F. (2014). "Bacteriological Assessment of the Quality of Brassica oleracea var. capitata Grown in the Accra Metropolis, Ghana." Africa Journal Microbiology. Research, 8 (22): 2223-2228.

Prigulkar, K.A., Kamat, O and Bougiruwar, D. (2000). Microbiology Quality of Fresh Leafy Vegetables, Salad Components and Ready to Eat Salads. International Journal. Food Science Nutrition, 52: 15-23.

Reena, K., Milind, D., and Sushma, U. (2012). Microbiological Analysis of Street Vended Sugarcane luice from Bhilai City, India. Journal Of Pure And Applied Microbiology, Vol. 6(1), p. 375-380.

Said, D.E.S. (2012). Detection parasites in commonly consumed raw vegetables. Alex Journal Medicine, 48(4):345-352.

Sararaj P, D. Stella and D. Reetha, (2014). Microbial spoilage of vegetable and its control measures international journal of natural product science. 2(2): 1-12

Scallan, E., Hoekstra, R. M., Angulo, F. J., Tauxe, R. V., Widdowson, M. A., Roy, S. L., (2011) Foodborne illness Acquired in the United States-Major Pathogens. Emerging Infectious Disease, 17:7-15

Soltan MM, Dalla, M. Shojaei, M.K Sharifi Yazdi, S. Vahedi (2015). Microbial contamination of fresh vegetables and salad samples consumed in Tehran,Iran. Journal of Food Quality and hazard control. 2:139143

Sospedra, I., Rubert, J., Soriano, J.M. and Mañes, J. (2013). Survey of microbial quality of plant-based foods served in restaurants. Food Control, 30(2):418-422.

Sujeet, K.M. and Vipin, K. (2017). A study on prevalence of microbial contamination on the surface of raw salad vegetables: a study of Dhanbad City, India. International Journal Engineering Science Reserach, 2(10):1437-1442.

Tambekar, D. H. and Mundhada, R. H. (2006). Bacteriological quality of salad vegetables sold in Amravati city, India.

Udo, S., Andy, I., Umo, A. and Ekpo M. (2009). Potential Human pathogen (Bacteria) and their antibiogram in ready to eat salad sold in Calabar, South-South, Nigeria. The internet journal of tropical Medicine, 5 (2).

Uzeh RE, Alade FA, Bankole M, (2009). THE Microbial quality of Pre-packed mixed vegetables

salad in some retail outlets in Lagos, Nigeria. Africa Jouranl of Food Science. Vol3(9), pp. 270-272.

World Health Organization [WHO]. (2011). Initiative to estimate the Global Burden of

Foodborne Diseases: Information and publications. Retrieved June 26, from http://www.who.int/foodsafety/foodborne_disease/ferg/en/index 7.html 